\title{
PENGEMBANGAN LEMBAR KERJA MAHASISWA (LKM) MELALUI PEMBELAJARAN PROBLEM SOLVING PADA PERKULIAHAN DASAR-DASAR STATISTIKA
}

\author{
Sukmawati ${ }^{1}$, Rio Fabrika Pasandaran ${ }^{2}$, Mufidah $^{3}$ \\ Universitas Cokroaminoto Palopo ${ }^{1,2}$, Universitas Tadulako ${ }^{3}$ \\ sukmawati.math@yahoo.com ${ }^{1}$, riolovemath@gmail.com ${ }^{2}, \underline{\text { fida.mathc@gmail.com }}$
}

\begin{abstract}
Abstrak
Penelitian ini bertujuan untuk mengambangkan Lembar Kerja Mahasiswa (LKM) melalui pembelajaran Problem Solving pada perkuliahan dasar-dasar Statistika. LKM dikembangkan menggunakan model 4D dari Thiagarajan yakni define, design, develop, \& disseminate. Hasil penelitian menunjukkan bahwa; (1) LKM yang dikembangkan dinyatakan valid dengan skor rata-rata penilaian dua validator 4,45 berada pada kategori sangat baik, (2) LKM dikembangkan dinyatakan praktis dengan indikator rata-rata keterlaksanaan pembelajaran $78,67 \%$ berada pada kategori baik dan rata-rata respon mahasiswa sebesar 2,89 berada pada kategori baik, (3) LKM dikembangkan dinyatakan efektif dengan indikator persentase ketuntasan pemahaman konsep sebesar $77,14 \%$ berada pada kategori tinggi dan pemecahan masalah sebesar $71,43 \%$ berada pada kategori tinggi.

Kata Kunci : lembar kerja mahasiswa, problem solving, statistika
\end{abstract}

\section{A. Latar Belakang}

Statistika sebagai salah satu cabang matematika juga mewarisi sifat-sifat di atas. Ilmu statistika sangat berperan penting untuk memecahkan masalah perhitungan matematis dalam kehidupan sehari-hari. Oleh karena itu dibutuhkan kemampuan interpretasi dan ini merupakan hal yang rumit dan tidak banyak mahasiswa dapat menguasainya. Hal ini disebabkan karena kegagalan mahasiswa dalam memahami konsep statistika secara tersturktur. Pola ide dalam pikiran mereka bersifat acak, tanpa urutan, sehingga begitu rumit untuk membuat keputusan yang benar. Oleh karena itu pembelajaran statistika harus dimulai dengan cara sederhana dari konkrit ke abstrak, dari segi intuitif ke analisis, dari eksplorasi ke penguasaan dalam jangka waktu yang cukup lama, serta dari tahap yang paling sederhana hingga yang tinggi. Dengan cara ini, mahasiswa dapat membangun kemampuan mereka memecahkan masalah dan bermakna. Dalam pembelajaran bermakna, terdapat dua orientasi yakni, dosen menyajikan informasi/materi kepada mahasiswa melalui proses penerimaan dan penemuan. 
Kedua, mahasiswa diminta untuk mengaitakan materi/masalah yang disajikan dengan pengalaman dan pengetahuan yang telah mereka miliki sebelumnya. Dua dimensi ini berjalan secara simultan dan saling melengkapi (Gazali, 2016).

Untuk meningkatkan kualitas proses pembelajaran diperlukan strategi khusus dalam menyajikan materi. Salah satu materi yang ada dalam mata kuliah Dasardasar Statistika. Jika materi ini diberikan secara langsung dengan cara menjelaskan langkah-langkah pembuktian, maka mahasiswa tidak terlibat di dalam proses pembuktian tersebut. Aktivitas mereka hanya mencatat dan cenderung menghafalnya saja. Cara-cara belajar seperti ini bertolak belakang dengan psikologi belajar konstruktivis dan harus ditindaklanjuti oleh dosen sebagai pendidik dan pengajar. Pengembangan profesionalitas dosen akan berdampak pada perubahan pemikiran \& praktik pengajaran materi matematika tertentu. Olehnya setiap pengajar harus memberikan kesempatan yang seluas-luasnya kepada peserta didik untuk belajar, mengeksplorasi suatu masalah hingga pemikiran setiap peserta didik dapat diidentifikasi dengan baik (Fennemma \& Franke, 1992).

Dalam psikologi belajar konstruktivis, setiap mahasiswa diarahkan untuk membangun pengetahuan mereka sendiri melalui proses pengamatan, analisis informasi, penyusunan dugaan, pemecahan masalah, dan penarikan kesimpulan. Rangkuti (2014) menjelaskan bahwa gagasan utama psikologi belajar konstruktivisme adalah seorang pengajar tidak memindahkan pengetahuan kepada peserta didik. Justru peserta didiklah yang dituntut membangun pengetahuan mereka melalui kolaborasi dan rasionalisasi. Kolaborasi bermakna bekerjasama, berbagi ide, menjalin komunikasi guna memperoleh respon dari peserta didik lainnya, sedangkan rasionalisasi bermakna proses pemerolehan pengetahuan melalui aktivitas nalar. Oleh karena itu, setiap aktivitas pembelajaran harus diatur sebaik mungkin agar mahasiswa dapat membangun pengetahuan secara mandiri. Miao Li (2009) yang menjelaskan bahwa dalam belajar aktif peserta didik harus melakukan sesuatu yang lebih dari sekedar mendengarkan, mereka harus terlibat dalam tugas yang perlu pemikiran tingkat tinggi seperti tugas analisis, sintesis, dan evaluasi. Untuk mewujudkan hal tersebut maka perlu dikembangkan sebuah 
perangkat pembelajaran dalam bentuk lembar kerja mahasiswa (LKM). Oleh karena itu perlu dirumuskan beberapa fokus masalah sebagai berikut.

1. Bagaimana mengembangkan lembar kerja mahasiswa (LKM) melalui pemebelajaran Problem Solving pada perkuliahan dasar-dasar statistika yang memenuhi kriteria valid?

2. Bagaimana mengembangkan lembar kerja mahasiswa (LKM) melalui pemebelajaran Problem Solving pada perkuliahan dasar-dasar statistika yang memenuhi kriteria praktis?

3. Bagaimana mengembangkan lembar kerja mahasiswa (LKM) melalui pemebelajaran Problem Solving pada perkuliahan dasar-dasar statistika yang memenuhi kriteria efektif?

\section{B. Metode Penelitian}

Adapun jenis dari penelitian ini adalah penelitian pengembangan (research and development). Media yang dikembangkan adalah Lembar Kerja Mahasiswa (LKM) Problem Solving yang memenuhi kriteria valid, praktis, efektif. Penelitian ini dilaksanakan di Prodi Informatika UNCP, Mahasiswa Semester II tahun ajaran 2019/2020 sejak 25 Februari 2020 hingga 2 Mei 2020. Desain penelitian yang digunakan dalam penelitian ini adalah model pengembangan 4-D Thiagarajan. Model ini merupakan sistem pendekatan pengembangan pembelajaran yang dilaksanakan melalui 4 (empat) tahap, yaitu;

1) Define (Pendahuluan)

Memuat proses analisis pendahuluan, analisis mahasiswa, analisis ruang lingkup materi, dan analisis konsep

2) Design (Perencanaan)

Tahap perancangan merupakan tahap lanjutan dari tahap pendefinisian Setelah menganalisis kebutuhan bahan ajar, karakteristik mahasiswa, materi, konsep, dan penilaian. Langkah awal dari tahapan ini adalah pemilihan format yang dikembangkan meliputi nama media, konstruk media, tahapan pembelajaran, dan bentuk evaluasinya. 
3) Develop (Pengembangan)

Memuat proses validasi pakar, revisi, dan uji coba. Data dikumpulkan melalui teknik observasi, angket, dan tes. Proses observasi dilakukan untuk memperoleh data aktivitas belajar mahasiswa, sedangkan angket (respon) bertujuan untuk menggali respon mahasiswa tentang penggunaan media yang telah dikembangkan. Data dari kedua teknik ini selanjutnya digunakan untuk mengukur tingkat kepraktisan produk yang dikembangkan. Pengukuran kefektifan buku ajar dilakukan dengan melihat pencapaian hasil belajar mahasiswa. Hasil belajar diukur melalui tes pemahaman konsep dan pemecahan masalah. Analisis data dilakukan secara kualitatif dan kuantitatif. Data kuantitatif diperoleh dari angket lembar aktivitas pembelajaran mahasiswa, angket respon mahasiswa, dan tes pemahaman konsep \& pemecahan masalah. Data kualitatif berupa saran, komentar, dan kritik dari validator. Data-data yang telah terkumpul selanjutnya dianalisis untuk mengukur derajat valid, praktis, dan efektif dari media yang dikembangkan.

4) Disseminate (Penyebaran)

Penyebaran dilakukan melalui proses sosialisasi perangkat kepada kelompok dosen bidang kajian sebagai calon pengguna perangkat yang telah dikembangkan untuk memperoleh masukan atau saran-saran sebagai bahan pertimbangan dalam merevisi produk yang telah dikembangkan.

\section{Hasil Penelitian dan Pembahasan}

\section{a. Tahap Pendefinisian (Define)}

Kelas yang menjadi subjek dalam penelitian ini adalah kelas II F. Peneliti menelaah tentang latar belakang pengetahuan, bahasa yang digunakan dan tingkat pemahaman konsep dan pemecahan masalah. Hasil telaah yang dilakukan diperoleh bahwa tingkat pengetahuan mahasiswa hanya sebatas mengetahui (know) dalam artian bahwa sebagian besar mahasiswa lebih banyak mengahafal pelajaran daripada memahaminya. Sedangkan untuk tingkat pemahaman konsep dan pemecahan masalah, kemampuan mereka cenderung masih rendah sehingga masih sangat perlu dilatih dengan soal-soal pemahaman konsep dan pemecahan masalah. 
Berdasarkan hasil observasi awal, diketahui bahwa proses pembelajaran di kelas berlangsung secara konvensional yaitu pembelajaran yang dimana dosen menjelaskan konsep atau prosedur matematika disertai tanya jawab, kemudian memberikan contoh soal dan soal latihan. Walaupun demikian, dapat dikatakan bahwa pembelajaran yang dilaksanakan sudah berlangsung cukup baik dan mahasiswa cukup antusias dalam belajar statistika Selain itu, pembelajaran yang dilakukan juga belum memanfaatkan media pembelajaran yang disesuaikan dengan kebutuhan mahasiswa yaitu media LKM yang dapat lebih mendorong mereka mengeksplorasi materi lebih dalam. Selain hasil observasi proses kegiatan belajar mengajar, peneliti juga melakukan wawancara dengan dosen dan beberapa mahasiswa.

Dari hasil wawancara diperoleh suatu informasi bahwa pembelajaran yang dilaksanakan selama ini memang belum menggunakan media apapun. Selain itu terkait pemahaman konsep dan pemecahan masalah, dosen menyatakan bahwa pemahaman konsep dan pemecahan masalah mahasiswa cenderung rendah. Hal tersebut diperkuat dengan pernyataan dari beberapa mahasiswa yang diwawancarai oleh peneliti. Mahasiswa mengaku bahwa banyak materi matematika yang belum diketahui konsepnya dan ada juga mahasiswa yang mudah lupa dengan konsep yang pernah diajarkan sehingga dalam menyelesaikan persoalan tentang pemecahan masalah mereka masih merasakan kesulitan. Hasil wawancara dengan dosen juga diperoleh bahwa materi statisika merupakan materi yang sangat sulit bagi mereka. Sebagian besar mahasiswa kurang memahami statistika mereka seringkali bingung dengan materi tersebut apalagi jika mahasiswa diperintahkan untuk menganalisis gambar dan menginterpretasikannya (literasi kurang). Pencapaian pemahaman konsep dan pemecahan masalah mahasiswa dalam matematika bukanlah suatu hal yang mudah karena pemahaman terhadap suatu konsep matematika dilakukan secara individual. Seperti yang kita ketahui bahwa setiap mahasiswa mempunyai kemampuan yang berbeda dalam memahami konsep dan menyelesaikan masalah matematika. Sedangkan fakta di kelas menunjukkan bahwa tingkat pengetahuan mahasiswa hanya pada tingkat menghafal rumus saja.

Suherman (2001) mengemukakan bahwa inti dari pelajaran matematika adalah pemahaman. Seberapa hebat mahasiswa dalam menghafal berbagai rumus 
tidak akan bermanfaat jika konsep dasar tidak dipahami. Pemahaman konsep merupakan modal utama dalam menguasai materi matematika. Kendala yang dihadapi peneliti yaitu bagaimana mengembangkan LKM yang memuat kedua kemampuan tersebut guna meningkatkan hasil atau prestasi belajar mahasiswa. Pemahaman juga berkaitan dengan cara mahasiswa dalam menyusun proses pembuktian atau penemuan suatu rumus. Secara umum telah disepakati bahwa pemahaman mahasiswa tentang penalaran matematika "cenderung berkembang dari induktif menuju deduktif dan menuju generalitas yang lebih besar". Hierarki penalaran matematis menekankan pada perkembangan pola pikir induktif ke deduktif, namun mereka gagal menjelaskan secara memadai tentang jalan pikiran yang mereka tempuh. Dalam hal ini, mahasiswa melakukan transisi pemikiran dari penalaran induktif ke deduktif namun lemah dalam hal mengemukakan ide dasar yang mereka buat. (Eric Knutha, Orit Zaslavskyb, Amy Ellisc, 2019).

\section{b. Tahap Perancangan (Design)}

Tahap perancangan merupakan tahap lanjutan dari tahap pendefinisian Setelah menganalisis kebutuhan bahan ajar, karakteristik mahasiswa, materi, konsep, dan penilaian. Langkah awal dari tahapan ini adalah pemilihan format yang dikembangkan adalah sebagai berikut:

1) Nama Media

Media ini dirancang untuk memudahkan mahasiswa dalam memahami makna ukuran gejala pusat \& ukuran penyebaran melalui pemecahan masalah.

\section{2) Identitas Kelompok}

LKM dibagikan ke setiap mahasiswa dalam setiap kelompok. Setiap kelompok beranggotakan 5-6 mahasiswa. Format ini diharapkan dapat memudahkan mereka dalam mengeksplorasi masalah-masalah statistika.

3) Kegiatan pembelajaran

Media yang dikembangkan memuat dua kegiatan. Kegiatan pertama adalah kegiatan yang berhubungan dengan pemahaman konsep. Kegiatan kedua adalah kegiatan yang berhubungan dengan pemecahan masalah mahasiswa yakni kegiatan menghitung dan menyelesaikan masalah.

4) Soal Latihan 
Pada bagian akhir, disajikan soal latihan yang berisi soal-soal problem solving. Latihan ini bertujuan untuk mengetahui sejauh mana tingkat pemahaman konsep dan pemecahan masalah mahasiswa serta untuk mengetahui sejauh mana pemahaman mahasiswa terhadap materi yang telah dipelajari sebelumnya.

\section{c. Tahap Pengembangan (Develop)}

Tabel 1. Hasil angket penilaian media oleh validator

\begin{tabular}{lccc}
\hline \multicolumn{1}{c}{ Aspek penilaian } & \multicolumn{2}{c}{ Jumlah skor } & $\begin{array}{c}\text { Rata-rata tiap } \\
\text { aspek }\end{array}$ \\
\cline { 2 - 4 } & Validator 1 & Validator 2 & 4,3 \\
\hline $\begin{array}{l}\text { Kesesuaian materi/isi } \\
\text { Kesesuaian dengan pendekatan } \\
\text { pemahaman konsep }\end{array}$ & 47 & 39 & 4,5 \\
$\begin{array}{l}\text { Kesesuaian dengan pendekatan } \\
\text { pemecahan masalah }\end{array}$ & 15 & 12 & 4,8 \\
Bahasa & 15 & 14 & 4,5 \\
\hline \multicolumn{1}{c}{ Total skor } & 19 & \multicolumn{3}{c}{ 4,45 } \\
\hline \multicolumn{1}{c}{ Rata-rata skor } & \multicolumn{3}{c}{ Sangat baik } \\
\hline \multicolumn{1}{c}{ Kriteria }
\end{tabular}

Dari tabel di atas dapat dilihat bahwa rata-rata tiap aspek penilaian berada

pada rentang 4,2 - 5,0 atau $(4,2<\bar{x} \leq 5,0)$ sehingga dapat dikatakan bahwa kedua validator menilai produk yang dikembangnkan dengan kategori "sangat baik" dan media yang dikembangkan telah sesuai dengan kurikulum, karakteristik pemahaman konsep dan pemecahan masalah, serta bahasa yang digunakan telah sesuai dengan kaidah penulisan dan komunikatif. Selain itu, tabel di atas menunjukkan bahwa perolehan rata-rata skor dari kedua validator adalah sebesar 4,45 dengan kriteria "sangat baik". Hal ini menunjukkan bahwa media yang dikembangkan valid dan layak untuk diujicobakan.

\section{a. Kualitas Kepraktisan}

Penilaian kualitas kepraktisan dapat dilihat dari dua sumber, yaitu lembar observasi aktivitas mahasiswa selama empat kali pertemuan dan angket respon mahasiswa yang diberikan pada pertemuan kelima. Tabulasi data lembar observasi aktivitas mahasiswa dan angket respon mahasiswa dapat dilihat pada lampiran. Hasil analisis data tersebut dapat dilihat dalam paparan berikut.

1) Lembar observasi aktivitas mahasiswa

Pembelajaran berlangsung sebanyak 4 kali pertemuan. Pada setiap pertemuan dilakukan observasi aktivitas mahasiswa terkait penggunaan LKM. Ada dua orang observer disetiap pembelajaran dimana setiap observer mengamati masing-masing 
3 kelompok. Hasil analisis data lembar observasi secara lengkap dapat dilihat pada tabel berikut.

Tabel 2. Hasil observasi aktivitas mahasiswa

\begin{tabular}{lcc}
\hline \multicolumn{1}{c}{ Pertemuan } & Persentase $(\%)$ & Kriteria \\
\hline Pertemuan pertama & 61,76 & Kurang baik \\
Pertemuan kedua & 82,35 & Baik \\
Pertemuan ketiga & 85,29 & Sangat baik \\
Pertemuan Keempat & 85,29 & Sangat baik \\
\hline \multicolumn{1}{c}{ Rata-rata persentase } & 78,67 & Baik \\
\hline
\end{tabular}

Berdasarkan hasil tabel di atas dapat diketahui bahwa pembelajaran sudah berjalan sesuai yang diharapkan. Dengan begitu, media yang dikembangkan praktis digunakan dalam pembelajaran dengan rata-rata persentase 78,67\% dengan kriteria baik.

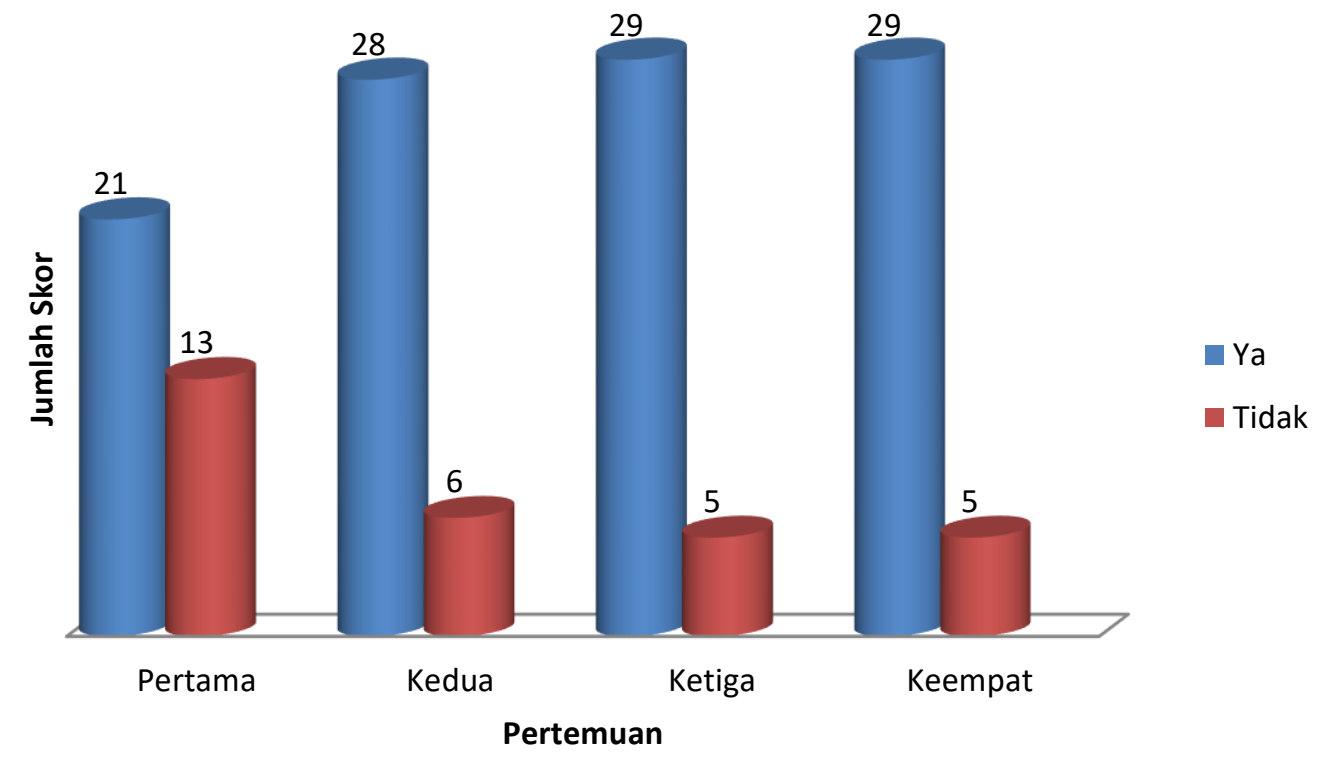

Gambar 1. Diagram Keterlaksanaan Aktivitas Mahasiswa

Gambar di atas merupakan diagram yang menunjukkan bahwa aktivitas mahasiswa dalam pembelajaran semakin meningkat dan membaik disetiap pertemuannya. Hal ini dapat dilihat dari jumlah skor yang diberikan observer pada pilihan "Ya" yang semakin meningkat sedangkan jumlah skor pada pilihan "Tidak" semakin menurun.

2) Angket Respon Mahasiswa 
Angket respon mahasiswa diisi oleh seluruh mahasiswa yang berjumlah 35 orang. Secara klausikal, nilai rata-rata total angket respon mahasiswa mencapai 2,89 dengan kriteria baik. Berdasarkan kriteria kepraktisan angket respon mahasiswa, menunjukkan bahwa media yang dikembangkan praktis digunakan dalam pembelajaran. Adapun respon mahasiswa terhadap penggunaan media disajikan pada tabel berikut ini.

Tabel 3. Hasil Angket Respon Mahasiswa

\begin{tabular}{lccc}
\hline \multicolumn{1}{c}{ Aspek penilaian } & Skor & Rata-rata & Kriteria \\
\hline Perhatian & 678 & 2,77 & Baik \\
Ketertarikan & 189 & 2,70 & Baik \\
Keyakinan & 604 & 2,88 & Baik \\
Kepuasan & 549 & 3,14 & Baik \\
\hline \multicolumn{1}{c}{ Total } & 2020 & 2,87 & Baik \\
\hline
\end{tabular}

Dari hasil tabel tersebut dapat dilihat bahwa pada aspek perhatian diperoleh skor 678. Hal ini menunjukkan bahwa mahasiswa senang belajar menggunakan media dan pembelajaran dengan memanfaatkan media membuat mahasiswa mudah memahami materi. Pada aspek ketertarikan diperoleh skor 189. Hal ini menunjukkan bahwa media yang dikembangkan tidak membosankan. Pada aspek keyakinan, diperoleh skor 604 yang menunjukkan bahwa media membuat mahasiswa termotivasi untuk belajar serta meningkatkan kemampuan mahasiswa. Sedangkan pada aspek kepuasan diperoleh skor 549 yang menunjukkan bahwa media bermanfaat bagi mahasiswa dan membuat mahasiswa berani dalam mengeluarkan pendapatnya. Kesimpulan dari tabel 16 yang disajikan adalah nilai rata-rata total angket respon mahasiswa tiap aspek mencapai 2,87 dengan kriteria baik.

Dari lembar angket respon mahasiswa juga diperoleh komentar dari mahasiswa terkait penggunaan media dalam pembelajaran. Beberapa komentar positif yang diberikan mahasiswa diantaranya adalah media yang digunakan sangat baik sehingga membuat mahasiswa lebih mudah memahami materi, penyajian media menarik mulai dari bentuk, warna, font serta gambar yang digunakan sampai pada kegiatannya. Sedangkan untuk komentar negatif salah satunya yaitu bahwa media yang digunakan susah/sulit dan membuat mereka bingung. 


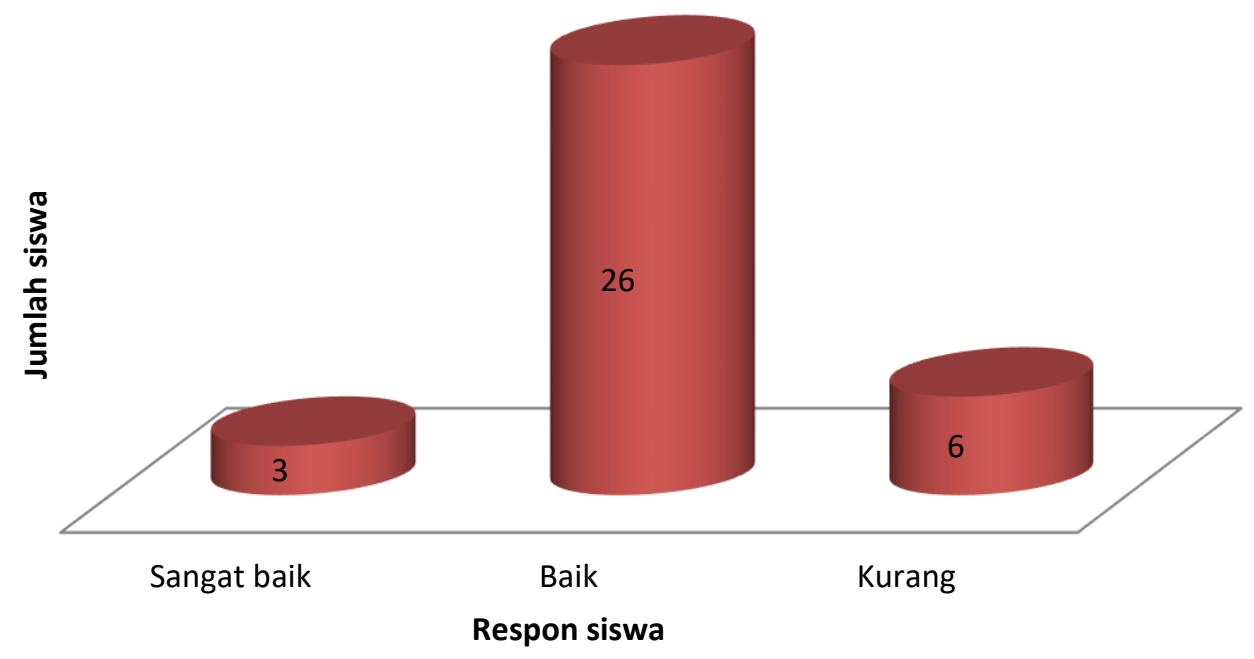

Gambar 2. Diagram respon Mahasiswa terhadap penggunaan LKM

Gambar di atas merupakan diagram yang menunjukkan bahwa sekitar $80 \%$ mahasiswa merespon positif LKM yang digunakan dalam pembelajaran. Hal ini dapat dilihat pada diagram dimana yang merespon baik penggunaan media sebanyak 26 mahasiswa dan yang merespon sangat baik sebanyak 3 orang.

\section{b. Kualitas Keefektifan}

Penilaian kualitas keefektifan dilihat dari hasil tes problem solving. Tes dilaksanakan pada pertemuan terakhir. Tes tersebut terdiri atas empat nomor dimana soal pemahaman konsep dan pemecahan masalah masing-masing terdiri atas dua nomor. Skor maksimum pada soal pemahaman konsep adalah 9 sedangkan pada soal pemecahan masalah adalah 28. Berdasarkan hasil analisis tes tertulis diperoleh nilai tertinggi yang diperoleh mahasiswa dari soal pemahaman konsep adalah 88,89 dengan jumlah skor yang diperoleh sebesar 8 sedangkan nilai terendah adalah 22,22 jumlah skor yang diperoleh mahasiswa sebesar 2. Nilai tertinggi yang diperoleh mahasiswa dari soal pemecahan masalah adalah 92,86 dengan jumlah skor yang diperoleh mahasiswa sebesar 26. Sedangkan nilai terendah adalah 35,71 dengan jumlah skor yang diperoleh mahasiswa sebesar 10. Hasil analisis tes secara lengkap dapat dilihat pada tabel berikut. 
Tabel 4. Kategori Problem Solving

\begin{tabular}{|c|c|c|}
\hline \multirow[b]{2}{*}{ Ketuntasan } & \multicolumn{2}{|c|}{ Jumlah } \\
\hline & $\begin{array}{l}\text { Pemahaman } \\
\text { konsep }\end{array}$ & $\begin{array}{l}\text { Pemecahan } \\
\text { masalah }\end{array}$ \\
\hline Mahasiswa yang tuntas (minimal kategori tinggi) & 27 & 25 \\
\hline $\begin{array}{l}\text { Mahasiswa yang tidak tuntas (maksimal kategori } \\
\text { tinggi) }\end{array}$ & 8 & 10 \\
\hline Persentase ketuntasan (\%) & 77,14 & 71,43 \\
\hline
\end{tabular}

Hasil analisis ini menunjukkan bahwa persentase ketuntasan untuk pemahaman konsep sebesar $77,14 \%$ dan persentase ketuntasan untuk pemecahan masalah sebesar $71,43 \%$. Berdasarkan persentase yang diperoleh tersebut menunjukkan bahwa media yang dikembangkan efektif digunakan dalam pembelajaran.

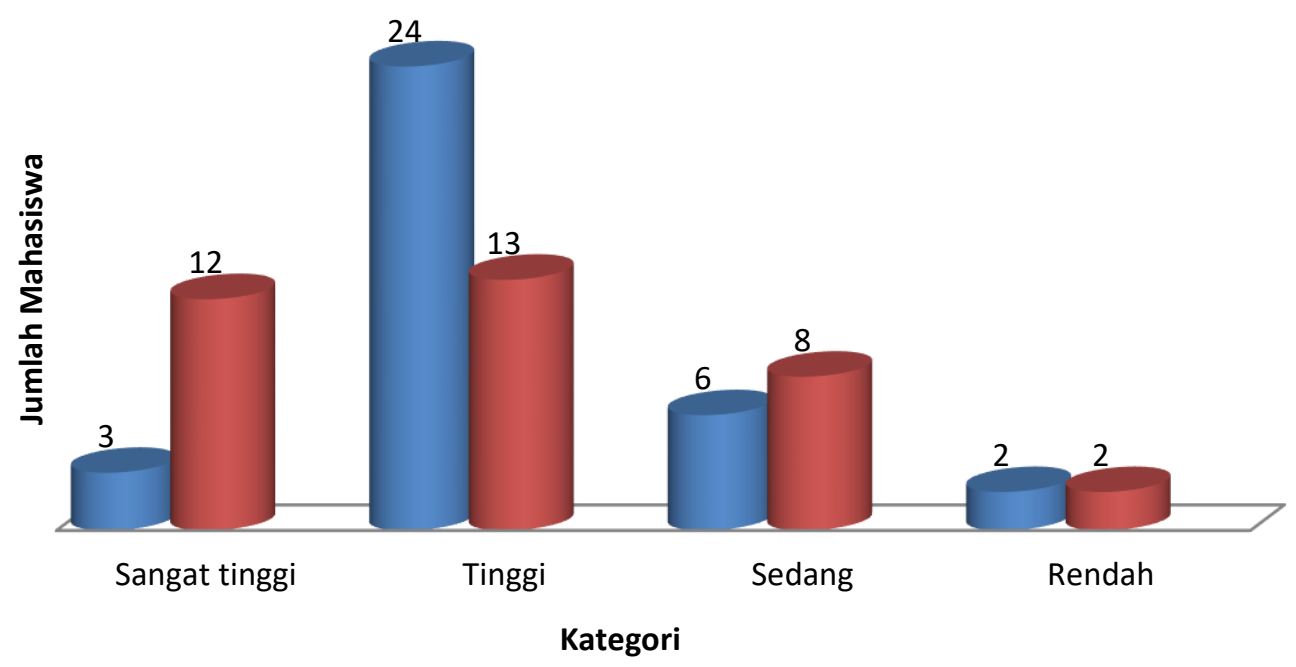

Gambar 4. Diagram Problem Solving Mahasiswa

Dari gambar di atas diperoleh fakta bahwa lebih banyak mahasiswa yang tuntas pada soal pemahaman konsep daripada soal pemecahan masalah. Diagram menunjukkan sebanyak 27 siswa dapat mengerjakan soal pemahaman konsep dan hanya 25 mahasiswa dapat mengerjakan soal pemecahan masalah. Terkait penggunaan LKM selama proses pembelajaran, terlihat bahwa mahasiswa merasa termotivasi mempelajari LKM. Apabila terdapat materi yang kurang jelas, mereka berusaha memahaminya dengan cara bertanya kepada mahasiswa pada kelompok lain ataupun bertanya langsung kepada dosen. 
Selain itu mahasiswa aktif mengerjakan semua soal yang terdapat dalam LKM. Sudjana (2004) menyatakan bahwa keaktifan mahasiswa dapat dilihat dalam hal: (1) Turut serta dalam melaksanakan tugas belajarnya; (2) Terlibat dalam pemecahan masalah; (3) Bertanya kepada mahasiswa lain atau dosen apabila tidak memahami persoalan yang dihadapinya; (4) Berusaha mencari berbagai informasi yang diperlukan untuk pemecahan masalah; (5) Melaksanakan diskusi kelompok sesuai dengan petunjuk dosen; (6) Menilai kemampuan dirinya dan hasil-hasil yang diperolehnya; (7) Melatih diri dalam memecahkan soal yang sejenis; (8) Kesempatan menggunakan atau menerapkan apa yang diperoleh dalam menyelesaikan tugas yang dihadapinya. Namun terdapat kelemahan mahasiswa pada tahap memeriksa kembali karena mereka lebih terpaku pada cara yang diajarkan dosen tanpa mengembangkan cara untuk menyelesaikan suatu permasalahan dengan cara mereka sendiri. (Zaslavsky, 2019) memaparkan beberapa cara untuk mengatasi kesulitan mahasiswa tersebut yaitu membiasakan mahasiswa untuk berpikir kritis melalui beragam contoh yang variatif. Makina, (2010) mengajukan suatu model dari proses berpikir kritis dimulai dengan memahami masalah, melakukan pengkajian terhadap bukti, dan data, melakukan pengkajian terhadap hal di luar bukti, data, dan asumsi di atas, menyatakan dan mendukung suatu kesimpulan, keputusan, dan menerapkan kesimpulan, keputusan, atau solusi.

Pertama-tama kita harus mengetahui respon mahasiswa terhadap suatu masalah secara spontan, apa yang mahasiswa lakukan, dan apa yang mereka pikirkan. Selanjutnya, kita mendorong mereka untuk untuk menelusuri semua informasi dalam contoh dan menuliskannya, sehingga mereka dapat menghasilkan contoh dengan bahasa mereka sendiri, kemudian memberi mereka contoh tambahan yang dapat menjelaskan nalar/pemikiran mereka. Pemikiran ini sejalan dengan aspek Analisis (C4) dalam level kognitif menurut taksonomi Bloom. Berpikir analitik penting dan layak untuk dikembangkan dalam bentuk pengetahuan tentang kapan dan bagaimana menggunakan contoh produktif untuk konseptualisasi dan pemikiran kritis (dugaan, pembuktian, pemecahan masalah) dalam pembelajaran dan pengajaran matematika. Keterampilan pemecahan masalah mahasiswa juga dapat dilihat dari cara mereke menulis proses pemecahan masalah secara sistematis. 
Menulis memungkinkan peserta didik dapat membangun sumber data yang relevan.

Sumber data ini memungkinkan mereka dapat menyusun diagram pemecahan masalah secara sistematis. Menulis merupakan salah satu bentuk komunikasi matematik yang menjadi kekuatan sentral bagi peserta didik dalam : (a) merumuskan konsep dan strategi matematik, (b) menjadi modal keberhasilan bagi mahasiswa dalam eksplorasi dan investigasi matematik, (c) wadah bagi peserta didik dalam berkomunikasi dengan temannya untuk memperoleh informasi, membagi pikiran dan penemuan mereka (Umar, 2012).

\section{d. Tahap Penyebaran (Disemination)}

Tahap penyebaran merupakan tahap penggunaan perangkat yang telah dikembangkan melalui tahapan validasi para ahli dan revisi. Dalam penelitian ini, tahap penyebaran media dilakukan melalui proses sosialisasi kepada kelompok dosen pengampu mata kuliah dasar-dasar Statistika dalam lingkup UNCP.

\section{Kesimpulan}

Berdasarkan hasil penelitian dan pembahasan diperoleh kesimpulan bahwa media LKM layak digunakan dalam pembelajaran ditinjau dari aspek kevalidan, kepraktisan, dan keefektifan yang diuraikan sebagai berikut:

1. LKM problem solving yang dikembangkan dinyatakan valid dengan skor ratarata penilaian dua validator 4,45 berada pada kategori sangat baik.

2. LKM problem solving yang dikembangkan dinyatakan praktis dengan indikator rata-rata keterlaksanaan pembelajaran $78,67 \%$ berada pada kategori baik dan rata-rata respon mahasiswa sebesar 2,89 berada pada kategori baik.

3. LKM problem solving yang dikembangkan dinyatakan efektif dengan indikator persentase ketuntasan pemahaman konsep sebesar 77,14\% berada pada kategori tinggi dan pemecahan masalah sebesar 71,43\% berada pada kategori tinggi.

\section{Daftar Pustaka}


Eric Knutha, Orit Zaslavskyb, Amy Ellisc. (2019). The role and use of examples in learning to prove. Journal of Mathematical Behavior, Vol. 53. (2019), $2-5$.

Fennemma, E., \& Franke, M. (1992). Teacher's Knowledge and Its Impact. New York: Handbook of Research on Mathematics Teaching and Learning

Gazali, R. Y. (2016). PEMBELAJARAN MATEMATIKA YANG BERMAKNA. Math Didactic: Jurnal Pendidikan Matematika, 185.

Makina, A. (2010). The role of visualisation in developing critical thinking in Mathematics. Perspectives in Education, Volume 28(1), March 2010, 25.

Miao Li, P. Y. (2009). Study on Effect of Mathematics Teachers' Pedagogical Content Knowledge on Mathematics Teaching . Journal of Mathematics Education June 2009, Vol. 2, No. 1, pp.55-68, 58.

Rangkuti, A. N. (2014). KONSTRUKTIVISME DAN PEMBELAJARAN MATEMATIKA. Jurnal Darul 'Ilmi Vol. 02, No. 02 Juli 2014, 28-29.

Sudjana. (2004). Manajemen Program Pendidikan untuk Pendidikan Nonformal dan Pengembangan Sumber Daya Manusia. Bandung: Falah Production.

Suherman. (2001). Strategi Pembelajaran Matematika Kontemporer. Bandung : Universitas Pendidikan Indonesia.

Umar, W. (2012). Membangun Kemampuan Komunikasi Matematis Dalam Pembelajaran Matematika. Infinity: Jurnal Ilmiah Program Studi Pendidikan Matematika STKIP Siliwangi. Vol. 1, No. 1. 2012, 2.

Zaslavsky, O. (2019). There is more to examples than meets the eye: Thinking with and through mathematical examples in different settings. Journal of Mathematical Behavior 53 (2019), 10. 